\title{
Representing Women On Screen In Egypt After 2011: Evolution And Revolution
}

\author{
Thomas Richard
}

\section{Introduction}

When the 2011 Revolution started, Egypt had already a long history of films dealing with the situation of women, and their relation to men. These films range from ancient classics such as Henry Barakat's The Open Door (1963) and The Sin (1965), I Want a Solution (Marzouk 1975), to more recent productions such as Scheherazade, Tell Me a Story (Nasrallah 2009), or 678 (Diab 2010), which, as they describe a society facing crisis, can be seen as announcing the political turmoil of the following years. Throughout these films, women tended to be represented in a Post-Third-Worldist cinematic perspective, that focused on women's situation through a dialectic opposition between domination and emancipation (Shohat 2004, 68). At the same time, Egyptian cinema also is also credited for creating a particular image of women, associated with movie stars in a country that takes pride in its star-system (Shafik 2007, 210). Women have also been at the core of the representation of the Egyptian nation, especially when it comes to the representation of the "children of the land" (Shafik 2007, 89), who have been represented as the quintessential Egyptians, and personifications of the country as a whole.

A great deal of media and scientific attention focused on the role of women during the Arab Spring (Al-Ali 2012, Newsom and Lengel 2012). This attention was particularly aimed at women's participation in the protests on Tahrir Square and at the way this participation renewed the appreciation of women's identity from a political point of view (Kadry 2015). At the same time, these women appeared to be facing gender-based violence during the demonstrations (Winegar 2012). Following Mubarak's resignation, women became targets of choice for the backlash against gender activism, coming either from passers-by during women's demonstration, or from the security forces (Sholkamy 2013), hinting at the difficulty Egypt and its society faced when trying to redefine gender relationships in the revolutionary context.

Our aim is to study how film directors, drawing from, and at the same time confronting this heritage of representations, tried to renew the representation of

\footnotetext{
* Associate Researcher, Université d'Auvergne, France. Cairo Studies in English (2018): https://cse.journals.ekb.eg/
} 
women in Egypt in the light of the Revolution. In doing so, they had to face the pre-revolutionary representations of society, in order to renew the national narrative (Rouxel 2017). Another issue was to deal with the Western attention directed at the women's situation during and after the Revolution, that could be interpreted as feminist orientalism (Lewis 2013, Mohanty, Russo and Torres 1991, 251), bearing the risk to segment the nation along lines of understanding that would have been more relevant to Western audiences than to the local one. Film directors and actors who took part in the Revolution, particularly through their participation in the Mosireen project, ${ }^{1}$ with the aim of filming and sharing the images of the Revolution, were witnesses of the women's role during the demonstrations. Many of them have tried to take part in the social and political debates in Egypt through the direction of movies that aim at representing the Revolution. The focus of these films is an attempt at the creation of a national narrative of the Revolution (Barsalou 2012). In this regard, these film directors chose to act as intellectuals (Winock 2004), following the steps of other cultural actors who decided to commit themselves to revolutionary causes (Dreyer 2013).

This paper will analyze films and TV series that have been directed in Egypt or by Egyptians abroad since the 2011 Revolution. These 21 productions encompass both fictional and documentary works. Beyond content analysis, we will use interviews given by the film directors in which they state their intents in the making of these movies, and their understanding of the women's situation. We will also use movie reviews, in order to see how these films were received, and how they were understood by the public. By doing so, we aim to contextualize the films in their political and cultural context, both in Egypt, and in the festivals during which they were screened abroad. In doing so, we follow the steps of Philippe Braud and Luc Boltanski, in their works to study identities and representations through the means of audiovisual products (Braud 1996, 20, Boltanski 2012,3), placing ourselves in a constructivist perspective. We also draw our methodology from Viola Shafik's seminal work on Egyptian cinema and its relation to the gender issue (Shafik 2007, 6, 119), as we intend to understand how the situation that she described has been changed by the 2011 Revolution.

To analyze how film directors have faced these issues, the first part of this paper will focus on how they tried to distinguish the post-revolution vision of women from the representation that was predominant before 2011. Then we will study how it has been linked to the representation of the nation, in particular through the use of the feminine allegory, which stands for the liberation of the Egyptian people, along lines that were drawn by preceding revolutions. In the end, we will see how film directors have tried to renew the filmic representations 
of women by linking them to the social and economic issues that were at the core of the 2011 demonstrations.

\section{Deconstructing the Regime's Claim of Women's Protection}

In the interviews, film directors assert their support for the Revolution, as does Yousry Nasrallah when presenting After the Battle (2012) at the Cannes Festival (Mandelbaum 2012). Some, as the collective behind 18 days (Arafa et al 2011), were deeply involved in the revolutionary movement. For the women among them, the issue of gender relations and the situation of women were crucial in their defiance of the rule of Hosni Mubarak (Telmissany 2016) and played a great part in their adhesion to revolutionary ideals. Highly educated, frustrated by the censorship (Mansour 2012), and sharing the social and political concerns that fueled the demonstrations, film directors, as a sociological group, were very close to the middle class that took up the streets in 2011 (Kandil 2012). Nevertheless, in their apprehension of women's representation after the Revolution, one key issue was to distinguish it from how it had appeared in the films that had been produced before 2011, and to dismantle the Mubarak regime's political use of this issue. This question appears to have been particularly important for film directors who shot their movies early during the period, when the Revolution was still happening. Part of the discourse of authoritarian Arab regimes was that they protected women's rights, and that, should they fall, these rights would be curtailed by the Islamist movements (AlAli 2012). They made use of women's rights to assert themselves towards their international partners, in Egypt through the action of Suzanne Mubarak (Zuhur 2001). In the same way, by granting shooting authorizations, or by using a more or less mild censorship, the regime could use the work of film directors to justify its policies on an international scale, appropriating their work in some way, even if they weren't among its supporters. Moreover, the weight of Post-ThirdWorldist culture in Egyptian cinema (Shohat 2004) meant that the regime, proclaimed successor of the Third-Worldist Nasserist Egypt, could insist on a clear-cut link between its policies and the issues explored by the film industry.

Therefore, it has been essential for film directors to deconstruct the regime's discourse in order to renew their apprehension of the women's question during and after the Revolution. To do so, it was necessary to make the regime's protection of women appear as a fraud. Yousry Nasrallah underlines this aspect by opening After the Battle with women discussing (real) images of genderbased violence during the 2011 Revolution. This is also exemplified by one of the segments of 18 Days in which a young coffee seller joins the Revolution after being dragged through the street by the security forces. The strength of this 
image is enhanced by the fact that this girl is made to appear as an embodiment of Egypt, as she wears the national colours: she has red hair, a white skin, and is draped in a black cloak. In both cases, the directors insist on the fact that genderbased violence comes from the security forces, in opposition to the selfproclaimed regime's protection of women.

This deconstruction of the regime's discourse is at the core of Tarik Saleh's The Nile Hilton Incident (2017). Drawing his inspiration from Suzanne Tamim's murder in 2008, Saleh describes a situation where proximity with the regime prevents from being pursued for having killed a woman. What is more is that Saleh chose to represent the victim as a free-spirited and independent woman, who, according to the Post-Third-Worldist narrative, would have been considered "emancipated," and whose death, in a "progressive" regime would have been a scandal. Nevertheless, he describes a situation in which it appears more important for government officials to gag the inspector in charge and the possible (also a woman) witness, than to look for the culprit. In this way, the film director wants to expose the proclaimed protection of women by the regime as a mystification and a lie: women appear to be protected only as long as this protection serves the authoritarian rule rather than the women themselves. These films consider that violence against women during the Revolution was not socially or religiously-driven, but that it was rooted in the political sphere, and used as a tool of control by the regime. In another segment, 18 Days follows two thugs who prepare to attack the protesters, with a special aim at young female demonstrators. The film makes clear that they are being used by the regime, who manipulates them, using their social and affective misery to its advantage. On the other hand, a woman is indeed protected in the film: she is a young demonstrator who sees her neighbour, a football fan, come to her rescue, when the protest she joined is charged by the police. This sequence appears as an homage to the part football fans played on Tahrir Square (Dorsey 2012, 412), but it also means that the people, and particularly women, do not need the regime's protection. According to this film, protection, if needed, can come from the people themselves. This can appear as a rather naive way of interpretation, as it paradoxically may reinforce patriarchal structures of dominance and social control of women, which are here ignored, or only interpreted as a political tool of the regime. This over-optimistic vision may reflect the hopes of the first stages of the Revolution, when the film was shot, during which the downfall of the regime appeared as the key to abolish all kinds of dominance. Films shot later, particularly by women, such as and Nawara (Khalil 2015), and Kamla Abu Zikry's works (Women's Prison 2014 and A Day for Women 2016) consider this view as an illusion, and, on the contrary, aim at interrogating the structural aspect of the patriarchal order. 
Post-revolutionary films go a step further to delegitimize the regime's discourse by broadening their scope of gender-based oppression, and not limiting it to women, as was the case in most of pre-2011 films on the subject. They represent a regime of oppression that attacks every man or woman in his sexual identity. Men are described as victims of a political oppression that takes advantage of their gendered identity to control them, by frustration and symbolic castration. Sins of the Flesh (El Hagar 2016) focuses on a character, representing the revolutionary youth driven to murder by being separated from the woman he loves by an old man who represents Mubarak's regime. Moreover, the main character in Winter of Discontent (Batout 2013) is a man traumatized by the sexually-oriented torture he suffered at the hands of the security forces (Tadros 2013), and who lost his virility in the process. Through such narratives, these films aim to represent the 2011 Revolution as a way for all Egyptians to regain their gender-based dignity. The image of castration is strong enough to be used by Yousry Nasrallah when filming Brooks, Meadows, and Lovely Faces (2016), which can be interpreted as a parable on the Egyptian Revolution. Set in the rural areas of the Daqahlia governorate, the film narrates an uprising triggered by the castration and death of a young man at the hands of the thugs paid by the local tyrant, who threatens the deceased's fiancée. For these film directors, the oppression of women should not be separated from a more general gendered oppression which has been exposed by the Revolution. The Revolution itself, as these films tend to show, has been a place where gendered identities and relations between men and women have been renewed by the renegotiation of the patriarchal bargain (Hafez 2012), as both men and women reclaim their dignity in the process. Accordingly, this renegotiation of the patriarchal order appears in films which portray the Revolution as a meeting place. Winter of Discontent, as well as three segments (out of ten) of 18 Days have focused on couples who meet or rekindle their affection through the new forms of relations created during the demonstrations on Tahrir Square, a theme that is also hinted at, in After the Battle. The demonstrations are shown as a space where both men and women can free themselves of the oppressive rule, meet as equals, and oppose together the regime's forces. Nevertheless, this view may also appear as overly optimistic, and, while understandably aimed at representing a feeling of unity among the people, it carries the risk of forgetting the specific gender-based oppression that women are facing.

\section{Women in the Revolution: From Demonstrations to National Symbols}

If demonstrations are represented as meeting places, this is to be linked to the particular experience of film directors during the demonstrations, and to the way 
of shooting films that imposed itself in the documentaries about Tahrir Square. Such documentaries include Stefano Savona's Tahrir (2012), From Queens to Cairo (Sadek 2012), The Square (Noujaim 2013), In Tahrir Square, Egypt's 18 Days of Unfinished Revolution (Alpert and O'Neill 2012), or Tahrir 2011, the Good, the Bad and the Politician (Ezzat, Amin and Salama 2011). When filming the demonstrations, all these directors have tended to adopt the same way of filming, described by Stefano Savona when he comments on his experience as a film director amidst the protesters (Savona 2012). All these documentaries are shot from within the crowd, focusing on a few witnesses, presented as average protesters, who describe their motivations and act as guides to the film director (Abbadi and Hammouda 2016, 182). This method of filming was influenced by the use of video by the protesters and by the experience of documentation led by the project Tahrir Cinema (Schoene 2012, 19). This representation imposed itself because it is perceived as carrying the true sense of the Revolution, and not betraying it by creating figureheads that would put in the shadow the massive popular movement of the demonstrations (El Hamamsy 2012, 45, El Hamamsy and Soliman 2013, 250, Adami 2016, 69).

In these documentaries, protesters appear meeting one another randomly but with enthusiasm, and debating endlessly during the 18 days that led to Hosni Mubarak's downfall. These films document a liberation of speech that is portrayed as gender-blind. The camera work insists on the presence of men and women of all social backgrounds, and all faiths among the demonstrators, and focuses on the feeling of national unity that prevailed on the Square (Challand 2011, 275). In this regard, these documentaries are coherent with the vision of a people regaining its gendered dignity, and aim at carrying the same message of national unity, also considering that the issue of patriarchal dominance should not interfere with the representation of the revolutionary movement.

Women are not presented as threatened in these films, except by the security forces. They appear as a part of the collective actor, and, as in the films about the Tunisian demonstrations, they are presented as equal partners to men in the Revolution (Khalil 2014, 186). The meaning of this type of filming is twofold. The first one is that film directors do not want to single out women within the Revolution. Even if filming the Revolution has a particular meaning for female directors such as Lara Baladi (Telmissany 2016), they wish to avoid presenting the Revolution in a feminist light (Khamis 2011), as this would segment the people, and give way to an interpretation made along Western categories bordering on orientalist feminism (Sjoberg and Whooley 2011). On the contrary, film directors focus on the global claim that Egyptians made for their rights. When a student evokes women's rights in Savona's Tahrir, she is answered by a fellow female student that this will have to be discussed with the new 
constitution, which, she adds, will have to highlight all kinds of rights, including women's rights. In From Queens to Cairo, the issue of women is treated along the same lines: women's rights are fundamental, but they are part of a national bargain that concerns all Egyptians.

The other interpretation for this way of representing the revolution lies in the cinematographic references to which film directors could relate while filming Tahrir. The film directors' choice of filming the people as a collective revolutionary actor follows the steps of Eisenstein (Sumpf 2004, 15) and Dziga Vertov (Hicks 2007, 22, 90). When shooting October (1927), Enthusiasm (1930) or Man with a Movie Camera (1929), Soviet film directors faced the same question, and the filming disposal which imposed itself to document the Tahrir Revolution bears strong resemblances to the solutions they adopted. The choice is to build a collective actor, by showing characters that represent various aspects of the people, in the Tahrir case, men and women, Muslims and Christians, rural and urban dwellers, and lower, middle and upper social classes. This type of film aims at presenting the people with a mirror in which each citizen could find his reflection. This is based on the idea that the people is also the public of the movie (Montebello 2003), and that the act of filming itself is part of the artists' revolutionary commitment. The Revolution is perceived as creating a new public and social space, which has to be filmed in a renewed aesthetics, that takes into account the people's transformation by the Revolution, in a move that links political and aesthetic avant-gardes (Heinich 2018, 196, 357). When it comes to fiction, women tend to be presented as allegories of the people in its revolutionary struggle. This is facilitated by the long identification of the Egypt's national allegory as a woman (Dickinson 2007, 137, Shafik 2007, 89). In the revolutionary context, film directors can assert this use of allegory on the nationalist iconography that was created in the struggle against British colonialism during the 1919 Revolution (Baron 2005, 57). Moreover, directors can situate themselves in another artistic revolutionary genealogy, that was inaugurated by the French Revolution, with the creation of Marianne as a female national allegory (Agulhon 1979, 2001) that embodies the national struggle and links it with a strong popular identity.

This tendency to use female characters as allegories of the nation is enhanced by the presence within Egyptian cinema of characters that embody the nation and are identified as "children of the land" (Shafik, 2007, 100). Often from a low rural social background, they are presented as enduring, witty, down-to-earth characters that are quintessentially Egyptians. In the case of women, this representation of the "women of the land" has been transformed to develop a discourse about the Revolution, in which they appear as Egyptian Marianne. 
Their description fits the coffee seller of 18 Days who takes part in the demonstrations and faces the violence of the security forces. The visual grammar of this film segment appears to have been influenced by Delacroix's painting: Liberty Leading the People, before turning to another classical theme of national struggles; that of the brutalized/raped nation (Shafik, 2007, 256). This segment opens a trend of films with a double level of understanding: one apparent, narrating some events linked to the Revolution, and another level in which the film director tries to offer a global understanding of the 2011 events through the use of allegories.

This interpretation is particularly clear in Sins of the Flesh (El Hagar, 2016), which appears as a parable about the $25^{\text {th }}$ January Revolution, of which echoes run through the movie (Kenigsberg 2017). Fatma, played by Nahed el-Sebai, embodies Egypt as one of these "children of the land", a young peasant girl, torn between her aging husband, a metaphor of Hosni Mubarak's power, who gives her security, but whom she doesn't love, and her young lover Ali, a representation of the Revolution, deeply marked by anger and frustration. As Fatma and her lover kill the husband, they fall prey to the landlord, who embodies economic power, and who steps in after the apparent master which he controlled, the husband, has disappeared. Fatma gives birth to a child of unknown father, and, as she and Ali drown during the climax of the film, clinging to each other, and destroying each other at the same time, this child remains alone, representing the fragile hopes born from the Revolution.

Nawara (Weissberg 2015), set in Cairo, follows a parallel path. The film focuses on Nawara, who works as a maid for a well-off family, which has close ties with the Mubarak administration. When the Revolution breaks out, the family flees abroad, leaving Nawara in charge of the house. The young woman dreams that the money that was stolen by corrupt officials would be redistributed to the people, which would give her the possibility to have her ill father-in-law being properly cured, and allow her to set a home with her husband, with whom she never could consummate her marriage, as they lack a place of their own. While the film describes in details the life of the most humble population of Cairo, it is also highly allegorical. Nawara embodies Mother Egypt taking care of her children, here represented by the little chickens Nawara raises. She is portrayed as a personification of the Egyptian people through her social background and good nature, typical of the cinematic "children of the land." Moreover, she appears to express the different components of the Egyptian people, being married to a Nubian, an identity that equates to a subaltern position in the Egyptian traditional film industry (Shafik 2007, 64). Frightened at first of the house's dangerous dog, she tames it, and it protects her later against an aggression by people, dressed in religious attire, who try to appropriate the 
house. This scene is a metaphor of how the director wants to represent a transformed relation between the people and the security forces through the 2011 Revolution, including Mohamed Morsi's presidency. On the other hand, Nawara's boss, who scorns the demonstrations, and who dyes his white hair, represents the aging regime, which has lost its link with the people. As such, the whole film has a dual level of understanding, one as the story of a young woman during the Revolution, and a deeper meaning as a parable of the Revolution itself, up to its end, when Nawara's dreams are shattered when she is arrested by security forces that appear as menacing as they were at the beginning, alluding to the repression that followed the Revolution.

This identification of women with the nation can be seen as problematic as it follows classical cinematographic themes. In this regard, the Revolution does not seem to have transformed the representation of women, contrary to the hopes nurtured by the documentaries that aimed at creating a revolutionary cinema, in which a transformed visual culture would mirror a transformed society. The same can be said about the TV series, Fad Eshtebak (2013) in which the female characters can be interpreted as embodiments of the various aspects of the nation, but ones that do not depart from the roles of characters that were assigned to women before the 2011 Revolution (mother from lower-class, young successful artist, etc...). The allegorical use of women, despite being appealing to film directors who try to build a discourse about the Revolution, tends to re-root women's representation in ancient stereotypes that are familiar to the audience, albeit transforming them to a certain extent, as in the case of the "girls of the land": in this respect, rather than of a visual revolution, one may speak of an evolution in the representation of women.

\section{Renewing the Representation of Women Via Social and Political Issues}

The choice of "women of the land" to represent women as revolutionary allegories hints at another question film directors had to face, which is the link between the representation of women and the social and economic issues that were at the core of the Arab Spring (Campante and Chor 2012). Nawara, as well as the coffee seller of 18 Days do not join the first stages of the Revolution, but they are represented demonstrating when they appropriate slogans that fit their aspirations, namely about social justice and human dignity. To film directors who portray themselves as participating in the political avant-garde of the Revolution, this cinematographic choice means that they cannot focus on women as a stand-alone question, if they want to reach a wide national audience. To act as committed intellectuals, they feel the need to "go to the people" (Lefcourt 2004,98 ), something they try to do through these characters that they model to 
mirror what they think are the expectations of working-class citizens. This thinking is in turn based on the disputed idea (Charpentier and Pierru 2006) that cinema, understood as a mass media, can be a powerful means to bring the ideals of the Revolution to the people (Thorn 2004). This appears all the more necessary to film directors as, despite the proclaimed diversity of the protesters that documentaries filmed on Tahrir Square, most of them appear to be of middle-class background, or belonging to the pauperized youth, which nevertheless possesses a strong cultural capital (Bourdieu 1979), rather than belonging to the lowest social classes.

Nawara, in this regard, is reminiscent of the peasants of Anne Roussillon's documentary (I Am the People, 2014), who live in a village near Luxor and who are not primarily concerned by with a revolution, that they perceive as a preoccupation of people who are more well-off than they are. In his comment on I Am the People, François Ireton (2015) has noted that these peasants, men and women, often have the feeling of being treated worse than their cattle. This is precisely the slogan that triggers Nawara's interest in the Revolution: "insaniyya" ("humanity"). As Nawara witnesses how her father-in-law is considered, in the hospital, as nothing more than a nuisance, being literally thrown out of his bed and left sitting in the corridor, this becomes the key to her involvement in the Revolution. This link between women and sociopolitical issues remains on an allegorical level in Nawara, but Yousry Nasrallah tries to conceptualize it and to put it into practice in his work. Nevertheless, his work illustrates the difficulty of filming women of a lower social class without patronizing them. Through his work on Scheherazade, Tell Me a Story, and About the Boys, the Girls and the Veil (1995), he had already dealt with the transformation of men and women relations along the lines of social barriers. But he goes a step further with After the Battle. The film focuses on the meeting between Reem, a revolutionary and a women's rights activist, and Mahmoud, a guide and horse rider at the Pyramids, who attacked the protesters on Tahrir on February $2^{\text {nd }}$. This meeting mimics Yousry Nasrallah's intention when he started shooting: as he explains in interviews (Mandelbaum 2012), Nasrallah chose to go filming near the Pyramids, making his crew and actors meet the actual inhabitants of the village who attacked the protesters. And he decided to build his movie following the interactions between these two groups. His aim was to take part in the building of the discourse about the 2011 Revolution, and to share the questions it raised within both groups. Very symbolically, the gender issue appears at the very start of the movie, when female demonstrators discuss behind closed doors the gender-based security forces' violence during the Revolution. These women are presented as belonging to the upper or upper-middle class, and Nasrallah juxtaposes spaces and social classes during the whole movie, with the 
activists living inside luxury apartments, as opposed to the much more modest horse riders, who are mainly filmed in the outside, until they all symbolically meet, during the demonstrations.

In Yousry Nasrallah's eyes, these choices are aimed at showing that the question of women's rights should not be considered as a concern only for the westernized elite, to whom Reem belongs, but that it should be de-westernized (Sreberny 2000) to be considered an Egyptian issue per se. At the same time, he insists on the idea that both groups should meet and learn from each other, and without trying to impose preconceptions on one another. Contrary to Reem's initial belief, Fatma, Mahmoud's wife, does not need to be "emancipated". She is a free-spirited woman, who holds her ground against her husband as well as against political activists who think they know better than her. But she is represented as deeply suffering from social stigma, and the economic hardships that she encounters. As the film director presents it, political courses aimed specifically at women are relevant, but only if they are linked to other social and economic forms of education that are directed to the village as a whole.

Nevertheless, this enterprise appears to some extent to be the wishful thinking of Yousry Nasrallah. Despite his intention, his film has been characterized as participating in the elite cinematic "bubble" at the Cannes Festival (Kermabon 2012). If Nasrallah insists that all characters should respect each other, the educational dimension that is inherent to his way of "going to the people" (Lefcourt 2004, Tarragoni 2014) can be perceived as patronizing, as the horse riders appear more as receiving this education than sharing with their counterparts on an equal basis. As such, the way the film links women's emancipation to other social issues tends to install a vertical relationship between the characters and ignores much of the globalized political and social culture of the horse riders (Singerman and Amar 2006, 313) by attributing these characteristics only to Reem and her friends.

In filming this movie, Yousry Nasrallah appears to have been, despite his intention, captive of his own representations. He tried to correct this when filming Brooks, Meadows, and Lovely Faces, based on Bassem Samra's idea, himself familiar with the working-class society of Dakahlia, where he comes from. In an interview (2017), Nasrallah states his desire to renew his audience's gaze on the working-class society, and his will to direct a movie that would take into account the social transformations that followed the Revolution (Rouxel 2017, 31). In this movie, women are portrayed at the forefront of the uprising against an unjust power, as their fate is what will define the orientation taken by the society: the oppression of women, through forced marriages in this case, is apprehended as the most visible part of a general oppressive system. In this 
regard, Nasrallah reuses the idea of a gender-based oppression used by the regime against the population as a whole that was developed in films shot during the first stages of the Revolution. At the same time, he appears to share the concerns that followed the Tunisian Revolution, in which women asked not to be considered as mere symbols, but as equal partners in the revolutionary movement (Khalil 2014), and puts great emphasis in his film on the role of women as the driving force of the uprising, while portraying them fighting against an unjust patriarchal order used by the local tyrant to his personal benefit. Still, this order in itself, is only partially put into question, as one of the main characters opposed to the tyrant is precisely a benevolent patriarch, whose social role is never questioned.

This interrogation of women's new place in the political arena is mirrored in Mohamed Diab's Clash (2016) where two of them express the dual reality of the new Egypt that emerged from the Revolution (Guth 2017). The film follows the debates of pro and anti-Morsi protesters who have been trapped together in a police van after being arrested. These two women, a student and a nurse, can, here again, be interpreted in an allegorical sense, as the film director intended to portray the two faces of Egypt that opposed each other during the process that led to the arrest of Mohamed Morsi. However, as the actors and the film director point out (2017), these characters go beyond their allegorical meaning to question the characteristics of women in the film industry. Being among the most important characters of the film, they embody the role of Egyptian women in the revolutionary process (Olimat 2013 61-70), and their will to make their own choices based on their own hopes and fears about the future. The pro-Morsi student, in particular, appears to be the driving force behind her family's political engagement, rather than her father who accompanies her. In this regard, she distinguishes herself from the ancient Post-Third-Worldist discourse that considered women as victims of Islamic movements as she is portrayed as a politically conscious and self-asserting character.

This search for creating new types of female characters has been particularly developed in Kamla Abu Zikry's post-revolutionary works, in Women's Prison (2014) and A Day for Women (2016) (Zohdi 2017 and El Shabrawy 2014), she departs from Yousry Nasrallah's militant attitude that did not serve him well with the local box-office and critique (Nasrallah 2017), and opened way to accusations of self-exoticism towards lower-class Egyptians (Zohdi 2016). On the contrary, Abu Zikry has long devoted her work to working-class people, to the point of being considered as filming "slum movies" (Andeel 2014). In contrast to Nasrallah's from-gender-to-social move, she focuses on the social issues. Her work is aimed at describing the social context of prison, or of the poor neighborhood of Cairo in which the events take place, before questioning 
the role women have in it. The goal of such a choice is to avoid imposing representations on the characters that are alien to them, and to portray accurately how issues that are specific to women resonate in such context. A Day for Women is focused on women who enjoy, for the first time, the possibility to be among themselves at a swimming pool. The film innovates as it offers a feminine look on women, who are filmed in a way deprived of eroticism, but with the aim of creating complex characters, that do not fit the classical dichotomy of oppression and liberation (Shohat 2004): the apparently most emancipated woman is also the one who condemned herself to remain a virgin and who appears a prisoner of her own life. In line with her previous work, Abu Zikry aims at presenting the female body in a new light (Shafik 2012, Gordon 2015) that allows her to question her audience's view on the situation of women.

Women's Prison adapts the 1982 play of the same name by feminist author Fatheyya al-Assal and reflects her interrogations in the light of the postrevolutionary context. As a political author, al-Assal was herself imprisoned several times, and considered social justice and women's rights to be two fights that should not be separated (Shabrawy 2014). By referring to this cultural background in 2014, Kamla Abu Zikry finds a way to reframe the issue of women's emancipation in its historical depth, and to strongly link it to the social and political frustrations that were at the core of the Revolution. At the same time, she sheds light on the particular frustrations and injustices experienced by women, reflecting on their present situation in post-revolutionary Egypt. In this endeavour, she appears as a leading figure among other directors who share the same concerns. A film like Factory Girl (Khan 2013), about the love story that unfolds between a worker and her supervisor in the textile industry, tries, as does Abu Zikry's work, to renew women representations in Egyptian cinema (Andeel and Evans 2014) by transforming its perspective from the inside. Although the film follows an apparently traditional narrative, it undermines it, and offers, from a grass-root perspective, a new way to articulate the three main issues that have been at the core of both the Egyptian cinema and the Revolution: gender, class and nation.

\section{Conclusion}

As the Egyptian film industry went through the Revolution and tried to portray it during the event and after, the representation of women appeared to be a crucial question when it came to defining the changes that occurred in Egypt's self-representation. While much media and scientific attention has been devoted to the role played by women during the demonstrations, the issue resonated deeper in the film industry that undertook the task of interrogating its stereotypes 
on this subject. At the same time, the filmic disposal used by documentaries and projects such as Mosireen during the revolution introduced new ways of representing the people during the revolution, which raised the question of how women could be portrayed as sociopolitical actors in the light of their involvement during the demonstrations. This raised major issues, such as selfexoticism and orientalist feminism, which have been a chief concern for film directors in their efforts to transform the image of women on the Egyptian screen. The use of allegories, linked to the characters of the "women of the land" has appeared as a way to offer a filmic narrative of the revolution that would allow at the same time to renew the image of women on screen. Other directors, such as Yousry Nasrallah, have chosen to "go to the people", and, acting as intellectuals, have tried to link issues that are specific to women with broader sociopolitical questions by experimenting new ways of filming. Still, it appears that such experiments do not seem to have fit the audience's expectations, as, beyond the militant videos produced by Mosireen, these films have met little success. Despite the fact that many film directors and actors took part in the revolution, it would be going too far to consider that the Egyptian cinema itself has become revolutionary, in the way post-1917 Soviet cinema can be considered a revolutionary cinema. Rather, as shown by the work of film directors such as Mohamed Diab, Kamla Aby Zikry, or Mohamed Khan, it appears that the 2011 Revolution has started a process of evolution within the Egyptian cinema that deeply transforms its representation of women, both towards the state, and towards the patriarchal structures. Before 2011, women were political objects on the screen, they have now increasingly become political subjects.

\section{Endnote}

${ }^{1} \mathrm{http}: / /$ mosireen.org/?page_id=6

\section{Works Cited}

Abbadi, Heba, and Sally Hammouda. 2016. "From Spectators to 'Spect-Actors': All Tahrir's a Stage." In Rewriting Narratives in Egyptian Theatre: Translation, Performance, Politics, edited by Sirkku Aaltonen and Areeg Ibrahim, New York: Routledge 180-201.

Adami, Elisa. 2016. "How Do you Watch a Revolution? Notes from the 21st Century." Journal of Visual Culture 15, no.1: 69-84. 
Agulhon, Maurice. 2001. Les métamorphoses de Marianne : l'imagerie et la symbolique républicaines de 1914 à nos jours. Flammarion.

-----. 1979. Marianne au combat : l'imagerie et la symbolique républicaines de 1789 à 1880. Flammarion-Pere Castor.

Al-Ali, Nadje. 2012 "Gendering the Arab Spring." Middle East Journal of Culture and Communication 5, no. 1: 26-31.

Andeel, 2014. "Egypt's Cinematic Gems: 'One-Nil." Madamasr, 11 January 2014.

https:/www.madamasr.com/en/2014/01/11/feature/culture/egyptscinematic-gems-one-nil/

Andeel and Jenifer Evans. 2014. "Factory Girl': A Sweet, Painful, Unsatisfactory Triumph.” Madamasr, 16 March 2014.

https://www.madamasr.com/en/2014/03/16/feature/culture/factory-girl-asweet-painful-unsatisfying-triumph/

Baron, Beth. 2005. Egypt as a Woman: Nationalism, Gender, and Politics. Berkley and Los Angeles: University of California Press,

Barsalou, Judy. 2012. "Post-Mubarak Egypt : History, Collective Memory and Memorialization."Middle East Policy 19, no. 2: 134-147.

Boltanski, Luc. 2012. Énigmes et complots. Une enquête à propos d'enquêtes. Editions Gallimard.

Bourdieu, Pierre. 1979. "Les trois états du capital culturel." Actes de la recherche en sciences sociales, 30, no. 1:3-6.

Braud, Philippe. 1996. "L'émotion en politique." Presses de Sciences Po, Paris.

Campante, Filipe R., and Davin Chor. 2012. "Why Was the Arab World Poised for Revolution? Schooling, Economic Opportunities, and the Arab Spring." Journal of Economic Perspectives 26, no. 2: 167-88.

Challand, Benoit. 2011. "The Counter Power of Civil Society and the Emergence of a New Political Imaginary in the Arab World." Constellations 18, no. 3: 271-283.

Charpentier, Isabelle, and Emmanuel Pierru. 2006. "Réseaux de sociabilité, circulation matérielle et symbolique des produits culturels en milieu populaire." Les peuples de l'art 1: 111-127.

Diab, Mohamed. 2017. Interview and making-of for the French DVD edition of Clash Pyramide videos.

Dickinson, Kay. 2007. “I Have One Daughter and That Is Egyptian Cinema': Azīza Amīr amid the Histories and Geographies of National Allegory." Camera Obscura: Feminism, Culture, and Media Studies 22, no.1 (64): 137177. https://doi.org/10.1215/02705346-2006-023 
Dorsey, James. 2012. "Pitched Battles: The Role of Ultra Soccer Fans in the Arab Spring." Mobilization: An International Quarterly 17, no. 4: 411-418.

Dreyer, Sylvain. 2013. Révolutions!: Textes et films engagés-Cuba, Vietnam, Palestine. Armand Colin.

Gordon, Joel. 2015. "Piety, Youth and Egyptian Cinema." In Islamism and Cultural Expression in the Arab World, edited by Abir Hamdar, Lindsey Moore, chapter 4, 103-121. New York and London: Routledge.

Guth, Stephan. 2017. "Dual Identities/Masking." Journal of Arabic and Islamic Studies 17: 484-491.

Hafez, Sherine. 2012. "No Longer a Bargain: Women, Masculinity, and the Egyptian Uprising." American Ethnologist 39, no.1: 37-42.

Hamamsy, Walid, and Mounira Soliman. 2013. "The Aesthetics of Revolution: Popular Creativity and the Egyptian Spring." In Popular culture in the Middle East and North Africa: A Postcolonial Outlook, edited by Walid El Hamamsy and Mounira Soliman, 246- 260.

Hamamsy, Walid. 2012. "Shooting Under Fire: Filmmaking and the Aesthetics of Resistance: An Interview with Omar Robert Hamilton." Wasafiri. 27, no. 4): 45-49.

Heinich, Nathalie. 2018. L'Élite artiste. Excellence et singularité en régime démocratique. Editions Gallimard, Paris.

Hicks, Jeremy. 2007. Dziga Vertov: Defining Documentary Film. London: IB Tauris.

Ireton, François. 2015 French edition DVD bonus interview for I am the People, Narratio Films.

Kadry, Ahmed. 2015 "Gender and Tahrir Square: Contesting the State and Imagining a New Nation.” Journal for Cultural Research 19, no. 2: 199-206.

Kandil, Hazem. 2012 "Why Did the Egyptian Middle-Class March to Tahrir Square?" Mediterranean Politics 17, no. 2: 197-215.

Kenigsberg, Ben. 2017. "In Sins of the Flesh, One Prison Replaces Another." The New York Times, 30 November 2017.

https:/www.nytimes.com/2017/11/30/movies/review-in-sins-of-the-fleshone-prison-replaces-another.html

Kermabon, Jacques. 2012. "Depuis la bulle cannoise." 24 Images. 158: 54-55. https://www.erudit.org/fr/revues/images/2012-n158-images0338/67651ac.pdf

Khalil, Andrea. 2014. "Tunisia's Women: Partners in Revolution." The Journal of North African Studies 19, no. 2: 186-199.

Khamis, Sahar. 2011. "The Arab 'feminist' spring?" Feminist Studies 37, no. 3: 692-695.

Lefcourt, Jenny. 2004. “Aller au cinéma, aller au peuple." Revue d'histoire moderne et contemporaine 4: 98-114. 
Lewis, Reina. 2013. Gendering Orientalism: Race, Femininity and Representation. London: Routledge.

Mandelbaum, Jacques. 2012. "Après la bataille: Yousry Nasrallah plante sa caméra place Tahrir, au carrefour du réel et de la fiction." Le Monde, 18 September 2012.

http://www.lemonde.fr/culture/article/2012/09/18/apres-la-bataille-yousrynasrallah-plante-sa-camera-place-tahrir_1761867_3246.html http://www.lemonde.fr/culture/article/2012/09/18/apres-la-bataille-yousrynasrallah-plante-sa-camera-place-tahrir_1761867_3246.html

Mansour, Dina. 2012. "Egyptian Film Censorship: Safeguarding Society, Upholding Taboos." Alphaville: Journal of Film and Screen Media,4. Cora: Cork Open Research Archive. https://cora.ucc.ie/bitstream/handle/10468/5754/ArticleMansour.pdf?sequen $\mathrm{ce}=1$

Mohanty, Chandra Talpade, Ann Russo, and Lourdes Torres., eds. 1991. Third World Women and the Politics of Feminism. Bloomington and Indianapolis: Indiana University Press.

Montebello, Fabrice. 2003. "Les deux peuples du cinéma: usages populaires du cinéma et images du public populaire."Mouvements 3: 113-119. https://www.cairn.info/revue-mouvements-2003-3-page-113.htm

Nasrallah Yousry. 2017. Interview and bonus leaflet for Brooks Meadows and Lovely Faces French DVD edition Pyramides video.

Newsom, Victoria A., and Lara Lengel. 2012 "Arab Women, Social Media, and the Arab Spring: Applying the framework of digital reflexivity to analyze gender and online activism." Journal of International Women's Studies 13 (5): 31-45.

Olimat, Muhamad, ed. 2013. Arab Spring and Arab Women. London : Routledge

Rouxel, Mathilde. 2017. "Performer les stéréotypes d'une nouvelle société. Cinémas tunisiens et égyptien postrévolutionnaires." Traits-d'Union 7: 30-37. Savona Stefano 2012 interview Tahrir French DVD edition Jour2Fête

Schoene, Dorothea. 2012. "Art in a Revolution: A Conversation with Lara Baladi." Afterimage. 39, no. 5: 19

Shabrawy Charlotte. 2014. "Women's Prison': A Ramadan TV Triumph." Madamasr, 12 August 2014.

https://www.madamasr.com/en/2014/08/12/feature/culture/womens-prisona-ramadan-tv-triumph/

Shafik, Viola. 2012. "Resisting Pleasure? Political Opposition and the Body in Arab Cinema." Resistance in Contemporary Middle Eastern Cultures. Routledge, 133-149. 
-----. 2007. Popular Egyptian Cinema: Gender, Class, and Nation. Oxford: Oxford University Press.

Shohat, Ella. 2004. "Post-Third-Worldist culture: Gender, Nation, and the Cinema." In Rethinking Third Cinema, edited by Anthony R. Guneratne and Wimal Dissanayake, 63-90. London: Routledge.

Sholkamy, Hania. 2013. "Gender, Activism, and Backlash: Women and Social Mobilisation in Egypt." BRIDGE Cutting Edge programme on gender and social movements. http://socialmovements.bridge.ids.ac.uk/case-studies.

Singerman, Diane, and Paul Amar, eds. 2006. Cairo Cosmopolitan: Politics, Culture, and Urban Space in the New Globalized Middle East. Cairo: American University in Cairo Press.

Sjoberg, Laura, and Jonathon Whooley. 2015. "The Arab Spring for Women? Representations of Women in Middle East Politics in 2011." Journal of Women, Politics \& Policy 36, no. 3: 261-284.

Sreberny, Annabelle. 2000. "Television, Gender, and Democratization in the Middle East." De-Westernizing Media Studies: 63-78.

Sumpf, Alexandre. 2004. "Le public soviétique et Octobre d'Eisenstein: enquête sur une enquête."1895. Mille huit cent quatre-vingt-quinze. Revue de l'association française de recherche sur l'histoire du cinéma 42: 5-34.

Tadros, Mariz. 2013. "Politically Motivated Sexual Assault and the Law in Violent Transitions: A Case Study from Egypt." Institute of Development Studies (IDS). Brief Supporting Evidence Report; 8.

https://opendocs.ids.ac.uk/opendocs/bitstream/handle/123456789/2950/ERB 8\%20Final\%20Online.pdf?sequence $=2$

Tarragoni, Federico. 2014. "Le peuple spectateur et l'émancipation démocratique: sur la sensibilité populiste en littérature." Raison publique 2: 199-222.

Telmissany, May. 2016 "Documenting Defiance: Women Film-Makers in Tahrir Square."Journal of African Cinemas 8, no. 1: 117-128.

Thorn, Jean-Pierre. 2004. "Cinéma populaire et cinéma du peuple." L'Homme et la société 4: 189-198.

Weissberg, Jay. 2015. "Film Review: Nawara." Variety, December 12, 2015. http://variety.com/2016/film/festivals/nawara-review-1201673821/

Winegar, Jessica. 2012. "The Privilege of Revolution: Gender, Class, Space, and Affect in Egypt." American Ethnologist 39, no. 1: 67-70.

https://cmes.uchicago.edu/sites/cmes.uchicago.edu/files/uploads/Pre-

Readings/Jessica\%20Winegar\%20-\%20The\%20Privilege $\% 20$ of $\% 20$

Revolution\%20\%28February\%202012\%29.pdf

Winock, Michel. 2016. Le Siècle des Intellectuels. Paris : Le Seuil. 
Zohdi Yasmine. 2017. "A Flawed Feminist Fable: Dissecting Kamla Abu Zikry's, A Day for Women.” Madamasr, 5 January 2017.

https://www.madamasr.com/en/2017/01/05/feature/culture/a-flawedfeminist-fable-dissecting-kamla-abu-zekrys-a-day-for-women/

Zohdi, Yasmine. 2016. "Does Yousry Nasrallah's Collaboration with Sobky Take Exoticism too Far?" Madamasr, 25 November 2016. https://www.madamasr.com/en/2016/11/25/feature/culture/does-yousrynasrallahs-collaboration-with-sobky-take-exoticism-too-far/

Zuhur, Sherifa. 2001. "The Mixed Impact of Feminist Struggles in Egypt During the 1990s." Middle East Review of International Affairs 5, no.1: 78-89.

\section{Filmography}

Abu Zikry, Kamla. 2016. A Day for Women. EMPC.

----. 2014. Women's Prison. Adl Group.

Alpert, John and Matthew O'Neill. 2012. In Tahrir Square, Egypt's 18 Days of Unfinished Revolution. HBO.

Arafa, Sharif et al. 2011. 18 days. Self-produced.

Barakat, Henry. 1965. The Sin. Misr Films.

-----. 1963. The Open Door. Misr Films.

Batout Ibrahim. 2012. Winter of Discontent Ein Shams Films

Diab, Mohamed. 2010. 678. New Century Productions.

----. 2016. Clash. Sampek Productions.

Dziga, Vertov. 1930. Enthusiasm. Ukraïnfilm.

-----. 1929. Man with a Movie Camera. VUFKU.

Eisenstein, Serguei. 1927. October. Sovkino.

El-Hagar, Khaled. 2016. Sins of the Flesh. Misr Films

Ezzat, Tamer, Ayten Amin and Amr Salama. 2011. Tahrir 2011, the Good, the

Bad, and the Politician. Film-Clinic, Amana Creative in association with WDR, Ingredients Productions, SANAD.

Khalil, Hala. 2015. Nawara. Red Star for Film production and distribution.

Khan, Mohamed. 2013. Factory Girl, Day Dream Art Production.

Marzouk, Said. 1975. I Want a Solution Misr Films.

Metwali, Hazem and Ahmed Anwar. 2013. Fad Eshtebak Radio One.

Nasrallah, Yousry. 2016. Brooks, Meadows, and Lovely Faces. Misr Cinema Company.

-----. 2012. After the Battle. New Century Production.

-----. 2009. Scheherazade, Tell Me a Story. Misr Cinema Company.

---- 1995. About the Boys, the Girls and the Veil. Ognon Pictures.

Noujaim, Jehane. 2013. The Square. Worldview Entertainment. 
Representing Women on Screen

Roussillon, Anne 2014. I Am the People. Hautlesmains Production.

Sadek, Sherif. 2012. From Queens to Cairo Akhnaton Films.

Saleh, Tarik. 2017. The Nile Hilton Incident. Atmo Production.

Savona, Stefano. 2012. Tahrir. Picofilms. 